\title{
Should interferons take front stage as an essential MS disease-modifying therapy in the era of coronavirus disease 2019?
}

Cole Maguire, Teresa Frohman, PA-C, MSCS, FANA, Scott S. Zamvil, MD, PhD, Elliot Frohman, MD, PhD, FANA, FAAN, and Esther Melamed, MD, PhD

Neurol Neuroimmunol Neuroinflamm 2020;7:e811. doi:10.1212/NXI.0000000000000811

In the unprecedented pandemic of the coronavirus disease 2019 (COVID-19) along with a limited clinical understanding on effective vaccines and therapies, there are currently many unknowns for patients with autoimmune conditions, such as MS, who require ongoing treatment with immunotherapies. As information is currently lacking on the immune effects of COVID-19 in the context of MS disease-modifying therapies (DMTs), a challenging clinical question being faced by patients and neurologists is whether to continue current DMTs for patients with MS and risk potentially greater morbidity and mortality due to COVID-19 infection vs discontinue DMT therapy and risk MS disease relapse. At this time, we desperately need data to guide which DMTs may best treat both COVID-19 and MS.

Impressively, there has been a rapid international medical response in repurposing several antiviral therapies toward COVID-19 treatment, including remdesivir, lopinavir, ritonavir, ribavirin, interferon-alpha (IFN- $\alpha$ ), and interferon-beta (IFN- $\beta)^{1,2}$ (NCT04315948). Type I interferons such as IFN- $\beta$ are of particular interest for patients with MS because these DMTs have been Food and Drug Administration-approved for use in MS since the 1990s. ${ }^{3}$ Interferons were originally discovered to "interfere" with viral replication and are classified as type I (IFN- $\alpha$, $\beta$, and $\omega$ ), type II (IFN- $\gamma$ ), or type III. In the human IFN- $\alpha$ family, there are 13 genes encoding several isoforms, many of which have been popularized for treatment. By contrast, human IFN$\beta$ is encoded by only 2 genes with a more limited number of commercially available recombinant isoforms. Between the type I interferons, IFN- $\beta$ has been primarily used in MS, whereas IFN- $\alpha$ has been commonly used in the treatment of viral infections, such as herpes zoster, hepatitis B and C, and HIV. However, there is also evidence to suggest that IFN- $\alpha$ may have beneficial effects in MS. For example, treatment with IFN- $\alpha 2$ a can lead to a reduction in MRI disease activity in patients with MS with neutralizing antibodies to IFN- $\beta .^{4}$

Different IFN- $\alpha$ and IFN- $\beta$ isoforms are currently being evaluated and compared for the treatment of COVID-19. Interferon signaling pathways seem to be significantly upregulated, especially during the most critical stages of pulmonary disease, with IFN- $\alpha$ serum levels correlating with disease severity during the peak of disease. ${ }^{5,6}$ Similarly, circulating IFN- $\beta$ has also been reported to increase during peak disease stages although IFN- $\beta$ levels remain elevated even after symptomatic improvement. ${ }^{5,6}$ These data suggest that IFN- $\alpha$ may have a key role in the reduction of the viral load during the peak of the COVID-19 disease, whereas IFN- $\beta$ may have a potential role in the reduction of viral replication over the entire course of the disease. Because interferons are known to induce different cytokines and genes in different cell types and organs, one important caveat to consider is the timing of interferon administration in COVID-19 and the possibility of dichotomous interferon effects during early vs later stages of the disease.

\author{
Correspondence \\ Dr. Melamed \\ esther.melamed@austin.utexas.edu
}

\section{MORE ONLINE}

\section{COVID-19 Resources}

For the latest articles, invited commentaries, and blogs from physicians around the world

NPub.org/COVID19

From the Department of Neurology (C.M., T.F., E.F., E.M.), Dell Medical School, Austin, TX; and Department of Neurology and Program in Immunology (S.S.Z.), University of California, San Francisco, CA.

Go to Neurology.org/NN for full disclosures. Funding information is provided at the end of the article.

The Article Processing Charge was funded by the authors.

This is an open access article distributed under the terms of the Creative Commons Attribution-NonCommercial-NoDerivatives License 4.0 (CC BY-NC-ND), which permits downloading and sharing the work, provided it is properly cited. The work cannot be changed in any way or used commercially without permission from the journal. 
IFN- $\alpha$ has already been used as an active treatment for COVID-19 in China. ${ }^{1}$ Both nebulized and subcutaneous forms of recombinant IFN- $\alpha$, IFN- $\beta 1 a$, and IFN- $\beta 1 b$ are also currently tested in COVID-19 clinical trials in combination with other therapeutics (NCT04315948, NCT04276688, NCT04293887, NCT04251871, and NCT04275388).

One of the largest current trials, the World Health Organization multinational SOLIDARITY trial, is currently evaluating 4 therapeutic regiments including (1) IFN- $\beta$ with ritonavir/lopinavir, (2) ritonavir/lopinavir without IFN- $\beta$, (3) chloroquine or hydroxychloroquine, and (4) remdesivir. ${ }^{2}$ Of note, nebulized preparation of IFN- $\alpha$ has been reported to improve delivery to the respiratory tract while also reducing common interferon side effects, such as fatigue and myalgias, symptoms that can also be a part of COVID-19 infection.

Although interferon therapies revolutionized MS management in the 1990s, more recently, interferons have been relegated to the backstage of the MS DMT armamentarium because of the emergence of more effective and better tolerated DMTs. Nevertheless, given the potential benefits of interferons in the treatment of COVID-19, an important question now is whether interferons should be again brought to the front stage of MS management. If data from ongoing clinical trials continue to support the benefit of interferons in the treatment of COVID-19, it is perhaps prudent to consider interferons as a first-line therapy in newly diagnosed patients with MS. In patients with MS on other DMTs, we could consider changing therapy to interferons or adding interferon therapy to the patient's current DMT. For patients with active MS, other potential treatment strategies may be to combine interferon therapy with pulsed intermittent corticosteroids or IV immunoglobulin given monthly to quarterly or with a DMT that has antiviral properties (e.g., teriflunomide ${ }^{7}$ ). In the latter case, a carefully formulated treatment plan tailored to the patient could provide a strategic advantage over cell depleting MS DMTs by virtue of the inherent multiplicity of actions of type I IFNs when used as part of combination therapy.

There are of course many unknowns regarding whether IFN- $\beta$ or IFN- $\alpha$ therapies would be effective in the management of COVID-19 and MS and which specific IFN- $\beta$ and IFN- $\alpha$ isoforms may best create this balance. It will also be important to continue to assess how treatments such as IVIG and steroids may impact MS and COVID-19. Furthermore, treatment decisions will vary depending on patient age, disease activity, comorbidities, and current DMT. Nevertheless, based on the long-standing clinical experience and long-term safety profile of IFN- $\beta$ use in patients with MS, interferons could be a critical therapy to treat both COVID-19 and MS during the unprecedented international pandemic, and we should reconsider interferons' place in the MS DMT armamentarium.

\section{Acknowledgment}

The authors thank Dr. William Schwartz for critical reading of the manuscript.

\section{Study funding}

This work was supported by the University of Texas Dell Medical School Start Up funding to E. Melamed. The corresponding author, E. Melamed, had the final responsibility for the decision to submit this manuscript for publication.

\section{Disclosure}

None to report. Go to Neurology.org/NN for full disclosures.

\section{Publication history}

Received by Neurology: Neuroimmunology \& Neuroinflammation April 19, 2020. Accepted in final form May 12, 2020.

\begin{tabular}{|c|c|c|}
\hline Name & Location & Contribution \\
\hline Cole Maguire & $\begin{array}{l}\text { Dell Medical School at } \\
\text { the University of } \\
\text { Texas at Austin }\end{array}$ & $\begin{array}{l}\text { Designed and } \\
\text { conceptualized study, } \\
\text { performed literature } \\
\text { searches, and wrote the } \\
\text { manuscript }\end{array}$ \\
\hline $\begin{array}{l}\text { Teresa } \\
\text { Frohman, PA- } \\
\text { C, MSCS, FANA }\end{array}$ & $\begin{array}{l}\text { Dell Medical School at } \\
\text { the University of } \\
\text { Texas at Austin }\end{array}$ & Reviewing and editing \\
\hline $\begin{array}{l}\text { Scott S. Zamvil, } \\
\text { MD, PhD }\end{array}$ & $\begin{array}{l}\text { University of } \\
\text { California, San } \\
\text { Francisco }\end{array}$ & Reviewing and editing \\
\hline $\begin{array}{l}\text { Elliot Frohman, } \\
\text { MD, PhD, } \\
\text { FANA, FAAN }\end{array}$ & $\begin{array}{l}\text { Dell Medical School at } \\
\text { the University of } \\
\text { Texas at Austin }\end{array}$ & Reviewing and editing \\
\hline $\begin{array}{l}\text { Esther } \\
\text { Melamed, MD, } \\
\text { PhD }\end{array}$ & $\begin{array}{l}\text { Dell Medical School at } \\
\text { the University of } \\
\text { Texas at Austin }\end{array}$ & $\begin{array}{l}\text { Designed and } \\
\text { conceptualized study, } \\
\text { performed literature } \\
\text { searches, and wrote the } \\
\text { manuscript }\end{array}$ \\
\hline
\end{tabular}

\section{References}

1. Dong L, Hu S, Gao J. Discovering drugs to treat coronavirus disease 2019 (COVID-19). Drug Discoveries Ther 2020;14:58-60.

2. Kupferschmidt K, Cohen J. WHO launches global megatrial of the four most promising coronavirus treatments [online]. Science; 2020. Available at: https://www.sciencemag. org/news/2020/03/who-launches-global-megatrial-four-most-promising-coronavirustreatments. Accessed March 30, 2020.

3. Axtell RC, Steinman L. Type 1 interferons cool the inflamed brain. Immunity $2008 ; 28$ : 600-602.

4. Myhr K, Riise T, Lilleås FG, et al. Interferon- $\alpha 2$ a reduces MRI disease activity in relapsing-remitting multiple sclerosis. Neurology 1999;52:1049.

5. Huang L, Shi Y, Gong B, et al. Blood single cell immune profiling reveals the interferon-MAPK pathway mediated adaptive immune response for COVID-19. medRxiv 2020.03.15.20033472; doi: 10.1101/2020.03.15.20033472.

6. Wei L, Ming S, Zou B, et al. Viral invasion and type I interferon response characterize the immunophenotypes during COVID-19 infection. CELL-D-20-00887. Available at SSRN: https://ssrn.com/abstract $=3564998$ or http://dx.doi.org/ 10.2139/ssrn.3564998.

7. Gilli F, Li L, Royce DB, DiSano KD, Pachner AR. Treatment of Theiler's virusinduced demyelinating disease with teriflunomide. J Neurovirol 2017;23: $825-838$. 


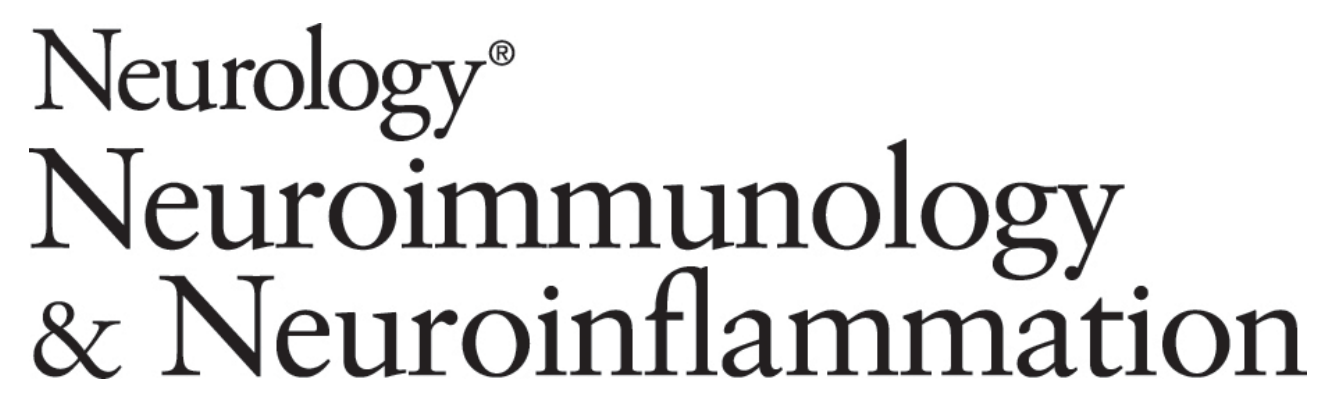

Should interferons take front stage as an essential MS disease-modifying therapy in the era of coronavirus disease 2019 ?

Cole Maguire, Teresa Frohman, Scott S. Zamvil, et al.

Neurol Neuroimmunol Neuroinflamm 2020;7;

DOI 10.1212/NXI.0000000000000811

This information is current as of June 11, 2020

Neurol Neuroimmunol Neuroinflamm is an official journal of the American Academy of Neurology.

Published since April 2014, it is an open-access, online-only, continuous publication journal. Copyright

Copyright $\odot 2020$ The Author(s). Published by Wolters Kluwer Health, Inc. on behalf of the American

Academy of Neurology.. All rights reserved. Online ISSN: 2332-7812.

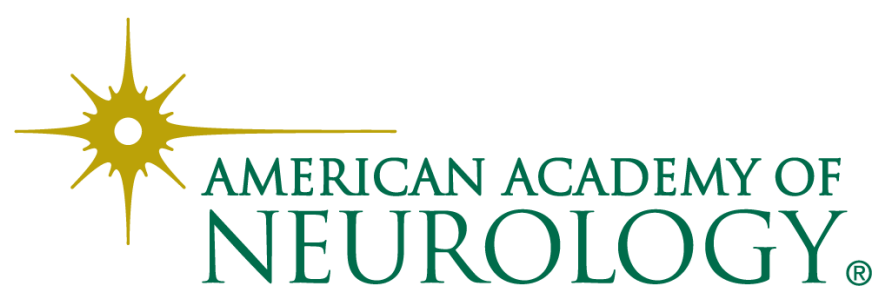




\section{Updated Information \& Services}

References

Citations

Subspecialty Collections

Permissions \& Licensing

Reprints including high resolution figures, can be found at: http://nn.neurology.org/content/7/5/e811.full.html

This article cites 5 articles, 1 of which you can access for free at: http://nn.neurology.org/content/7/5/e811.full.html\#\#ref-list-1

This article has been cited by 1 HighWire-hosted articles: http://nn.neurology.org/content/7/5/e811.full.html\#\#otherarticles

This article, along with others on similar topics, appears in the following collection(s):

\section{All Clinical trials}

http://nn.neurology.org//cgi/collection/all_clinical_trials All Immunology http://nn.neurology.org//cgi/collection/all_immunology COVID-19

http://nn.neurology.org//cgi/collection/covid_19

Multiple sclerosis

http://nn.neurology.org//cgi/collection/multiple_sclerosis

Information about reproducing this article in parts (figures,tables) or in its entirety can be found online at:

http://nn.neurology.org/misc/about.xhtml\#permissions

Information about ordering reprints can be found online: http://nn.neurology.org/misc/addir.xhtml\#reprintsus

Neurol Neuroimmunol Neuroinflamm is an official journal of the American Academy of Neurology.

Published since April 2014, it is an open-access, online-only, continuous publication journal. Copyright

Copyright $\odot 2020$ The Author(s). Published by Wolters Kluwer Health, Inc. on behalf of the American Academy of Neurology.. All rights reserved. Online ISSN: 2332-7812.

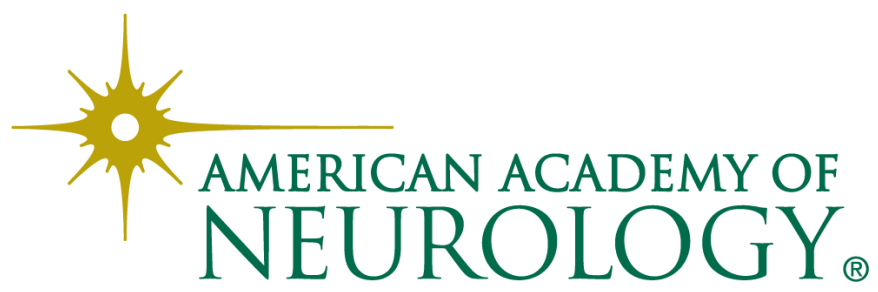

